University of Nebraska - Lincoln

DigitalCommons@University of Nebraska - Lincoln

USDA National Wildlife Research Center - Staff Publications
U.S. Department of Agriculture: Animal and Plant Health Inspection Service

March 2001

\title{
IMPACTS OF SUPPLEMENTAL FEEDING ON THE NUTRITIONAL ECOLOGY OF BLACK BEARS
}

\author{
Steven T. Partridge \\ Washington State University, Pullman, WA \\ Dale L. Nolte \\ USDA-APHIS-Wildlife Services, Dale.L.Nolte@aphis.usda.gov \\ Georg J. Ziegltrum \\ Washington Forest Protection Association \\ Charles T. Robbins \\ Washington State University, Pullman, WA
}

Follow this and additional works at: https://digitalcommons.unl.edu/icwdm_usdanwrc

Part of the Environmental Sciences Commons

Partridge, Steven T.; Nolte, Dale L.; Ziegltrum, Georg J.; and Robbins, Charles T., "IMPACTS OF SUPPLEMENTAL FEEDING ON THE NUTRITIONAL ECOLOGY OF BLACK BEARS" (2001). USDA National Wildlife Research Center - Staff Publications. 578.

https://digitalcommons.unl.edu/icwdm_usdanwrc/578

This Article is brought to you for free and open access by the U.S. Department of Agriculture: Animal and Plant Health Inspection Service at DigitalCommons@University of Nebraska - Lincoln. It has been accepted for inclusion in USDA National Wildlife Research Center - Staff Publications by an authorized administrator of DigitalCommons@University of Nebraska - Lincoln. 


\title{
IMPACTS OF SUPPLEMENTAL FEEDING ON THE NUTRITIONAL ECOLOGY OF BLACK BEARS
}

STEVEN T. PARTRIDGE, School of Biological Sciences, Washington State University, Pullman, WA 99164-4236, USA

DALE L. NOLTE, U.S. Department of Agriculture/APHIS, Olympia Field Station, 9730-B Lathrop Industrial Drive SW, Olympia, WA 98512, USA

GEORG J. ZIEGLTRUM, Washington Forest Protection Association, 724 Columbia Street NW, Suite 250, Olympia, WA 98501, USA

CHARLES T. ROBBINS, ${ }^{1}$ Department of Natural Resource Sciences and School of Biological Sciences, Washington State University, Pullman, WA 99164, USA

\begin{abstract}
Black bear (Ursus americanus) damage to managed conifer stands during the spring in the U.S. Pacific Northwest is a continuing management concern. Because bear damage to managed conifers may reflect the limited availability of nutritious foods, supplemental feeding has been used to decrease damage. Highly palatable, pelleted feed is provided ad libitum from April until late June when berries ripen and such damage stops. We examined black bear use of supplemental feed during the spring and summer of 1998 and 1999 in western Washington. Bears were captured in areas where supplemental feed was provided and in control areas where no effort to reduce conifer damage occurred. Mass gains for bears captured twice were $153 \pm 119 \mathrm{~g} / \mathrm{day}(\bar{x} \pm \mathrm{SD})$ in the fed areas and $12 \pm 104 \mathrm{~g} /$ day in non-fed areas. Fat gain for bears in the fed areas was $42 \pm 50 \mathrm{~g} / \mathrm{day}$ and $4 \pm 59 \mathrm{~g} / \mathrm{day}$ in the non-fed areas. However, because age-specific body masses and fat content did not differ between the 2 areas, short-term pellet feeding probably has no long-lasting effect on bear condition or productivity. The diet of bears in the fed areas was $55 \pm 22 \%$ pelleted feed, $7 \pm 7 \%$ animal matter, and $38 \pm 18 \%$ vegetation. The diet of bears in the non-fed areas was $13 \pm 17 \%$ animal matter and $87 \pm 17 \%$ vegetation. Grass and sedge composed the majority of vegetation consumed in both areas. The energy content of Douglas-fir (Pseudotsuga menziesii) and western hemlock (Tsuga heterophylla) sapwood was more digestible (60-67\%) than grasses and forbs (18-47\%). Smaller bears (adult females and subadult males and females) may do most of the damage because sapwood harvesting rates minimize nutritional gain to larger adult males.
\end{abstract}

JOURNAL OF WILDLIFE MANAGEMENT 65(2):191-199

Key words: black bear, body composition, conifer damage, diet, nutrition, stable isotopes, supplemental feeding, Ursus americanus.

Tree damage attributed to black bears occurs widely throughout western Washington, United States (Poelker and Hartwell 1973, Flowers 1987). Damage follows emergence of bears from winter dens and coincides with the period of new sapwood growth (Flowers 1987). Bears harvest sapwood (phloem and xylem oleoresin located immediately underneath the cork cambium [Kimball et al. 1998a]) by removing bark with their claws and scraping the vascular tissues with their incisors. Damage is concentrated in 15- to 25-year-old stands of managed conifer trees. In the Pacific Northwest, bears frequently damage Douglas-fir (Poelker and Hartwell 1973), but other conifers also are damaged (Lutz 1951, Glover 1955, Watanabe 1980, Mason and Adams 1989). Damage within the affected stands can be extensive because a single bear may peel bark from 50-70 trees a day. Peeling results in partial or complete girdling of the tree, causing death or

\footnotetext{
${ }^{1}$ E-mail: ctrobbins@wsu.edu
}

reduced growth (Poelker and Hartwell 1973, Nelson 1989, Hennon et al. 1990). Stand damage generally declines as summer foods, such as berries, become available during July.

Several attempts have been made to reduce damage by decreasing bear populations through hunting, but none have been completely effective. Unrestricted lethal control is also becoming politically less popular, as indicated by the passage of Initiative 655 in 1996 (RCW 77.16, Section 1), which banned recreational hound and bait hunting of bears in Washington. Thus, non-lethal methods of protecting timber stands are being explored. One widely used method is supplemental feeding, which provides bears with an alternate food source until summer berry crops become available. The number of feeding stations in western Washington has increased from 10 in 1985 to 850 in 1997 , with over $300,000 \mathrm{~kg}$ of pellets fed annually at a cost of over $\$ 300,000$ (Pickell 1997).

Newly formed sapwood is high in sugars but relatively low in protein (Radwan 1969, Kimball et al. 1998a). Thus, if sapwood is simply an important 
early spring food resource, supplemental feeding may be the most effective way to reduce damage. However, supplemental feeding may only delay the problem if it creates more productive bear populations that might ultimately increase damage if not combined with lethal solutions. Thus, the objectives of this study were to (1) determine the use and nutritional importance of supplemental feeding stations, and (2) provide a nutritional understanding of sapwood feeding.

\section{STUDY AREAS}

We selected several areas in western Washington as treatment and control areas. Treatment areas were located south of Capital Forest near Olympia on timber stands managed by Weyerhaeuser Company. Feeders have been used in these areas during previous years to reduce stand damage (G. Jones, J \& M Forestry, Olympia, Washington, personal communication). Feeders are installed and pelleted feed produced by the Washington Forest Protection Association is provided ad libitum from the onset of bear activity in the spring (mid-Apr) until bears no longer use the feeders as the availability of natural foods increases (early Jul). Control areas were on lands owned by the Washington Department of Natural Resources adjacent to treatment areas and represented similar habitat and vegetation types. Currently, no attempts are being made to control bear damage on Department of Natural Resources lands. Both study areas were dominated by managed, even-aged stands of Douglas-fir, although stands of western hemlock and western redcedar (Thuja plicata) were interspersed throughout the area.

\section{METHODS}

\section{Bear Capture and Measurements}

Bears were captured during early spring (Apr-May) and early summer (Jun-Jul). Early summer captures were conducted before berries matured and bears left the feeder areas. All bears were initially live-trapped using Aldrich foot snares (Johnson and Pelton 1980) or culvert traps. Bears were immobilized with a Palmer Cap-Chur gun using Telazol $(5.0-7.0 \mathrm{mg} / \mathrm{kg}$, Fort Dodge Laboratories, Fort Dodge, Iowa, USA). All bears were ear-tagged, and a passive integrated transponder (PIT tag) was injected subcutaneously for later identification (Avid Power Tracker II Multi Mode Reader, Norco, California, USA). Subadult and adult females and subadult males were radiocollared with standard VHF collars (Advanced Telemetry Systems, Isanti, Minnesota, USA) to increase the odds of recapture. As these age and sex classes typically gain mass in the spring (Noyce and Garshelis 1998, Rode and Robbins 2000), changes in mass and body composition can be used to indicate the nutritional value of their food resources. Adult males were not radiocollared as they frequently lose body mass in the spring while pursuing breeding opportunities (Noyce and Garshelis 1998).

Bears were weighed using an electronic loadcell $( \pm 0.2 \mathrm{~kg})$, blood-sampled for isotopic analysis of diet, and aged. During 1998, bears were categorized as cubs, subadults $(<4 \mathrm{yr})$, and adults ( $\geq 4 \mathrm{yr}$ ) based on tooth wear and body weight (Poelker and Hartwell 1973). During 1999, a premolar tooth was extracted for age estimation by cementum annuli (Matson's Laboratory, Milltown, Montana, USA). When possible, body composition was determined on anesthetized bears using both bioelectrical impedance analysis (Model BIA-101A, R.J.L. Systems, Detroit, Michigan, USA) and isotopic water dilution (Farley and Robbins 1994, Hilderbrand et al. 1998). However, time constraints occasionally prevented the use of water dilution and injuries occasionally prevented the use of BIA (Farley and Robbins 1994, Hilderbrand et al. 1998). Bears were recaptured by either live-trapping or with trained hounds that targeted specific bears. A minimum recapture interval of 4 weeks was used to ensure that mass changes could be measured accurately.

\section{Diet and Nutritional Analyses}

Diet was determined using stable isotope (Hilderbrand et al. 1996) and scat analyses (Hewitt and Robbins 1996). Blood plasma and red blood cells of captured bears were analyzed for $\delta^{13} \mathrm{C}(\% o)$ and $\delta^{15} \mathrm{~N}(\% o)$ on a Micromass Optima isotope ratio mass spectrometer (analytical precision: $\pm 0.1 \%$ for carbon and $\pm 0.2 \%$ or nitrogen) at the U.S. Geological Survey Lab in Denver, Colorado. Results are reported relative to PeeDee limestone $\left(\delta^{13} \mathrm{C}\right)$ or atmospheric nitrogen $\left(\delta^{15} \mathrm{~N}\right)$ as follows:

$$
\delta \mathrm{X}=\left[\left(\mathrm{R}_{\text {samples }} / \mathrm{R}_{\text {standard }}\right)-1\right] \times(1,000)
$$

where $\delta \mathrm{X}$ is $\delta^{13} \mathrm{C}$ or $\delta^{15} \mathrm{~N}$, and $\mathrm{R}$ is the ${ }^{13} \mathrm{C} /{ }^{12} \mathrm{C}$ or ${ }^{15} \mathrm{~N} /{ }^{14} \mathrm{~N}$ ratio (Peterson and Fry 1987). Due to the different turnover rates of blood fractions, both plasma and red blood cells were used for dietary estimation. Plasma represents the diet during the previous 10 days and red blood cells 
reflect the diet over the past 2-3 months (Hobson and Clark 1992, Hilderbrand et al. 1996).

Dietary contribution determined by stable isotopes is defined as the proportion of assimilated carbon and nitrogen derived from a particular source, and does not directly reflect biomass consumed because assimilation incorporates both digestibility and metabolizability, which vary depending on the food source (Pritchard and Robbins 1990, Hilderbrand et al. 1998). Hair samples from Columbian black-tailed deer (Odocoileus hemionus) were collected in the study area to determine an isotope signature of animals consuming only plant matter (Jacoby et al. 1999). The isotope signature of the pelleted diet was determined in ad libitum feeding trials using 3 captive black bears. After a minimum of 20 days, bears were anesthetized and plasma was collected for isotopic analyses. Because the pelleted feed contained significant amounts of cane sugar, which is from a tropical $\mathrm{C}_{4}$ plant and therefore depleted in ${ }^{13} \mathrm{C}$ relative to the $\mathrm{C}_{3}$ plants found in northern latitudes (Cormie and Schwarcz 1994), the carbon signature of wild bears was used to identify bears consuming pellets and determine the dietary contribution of pellets. Dietary content of the remainder of the diet, i.e., locally produced plant and animal matter, was determined from the trophic enrichment of ${ }^{15} \mathrm{~N}(+4.93$, Hilderbrand et al. 1996) occurring between plants and herbivores in the study area. Although the pellets contain meat and therefore a bear eating pellets will have an elevated ${ }^{15} \mathrm{~N}$ signature relative to a purely herbivorous bear, the meat content of the rest of the diet can be distinguished from that in the pellets by using both ${ }^{13} \mathrm{C}$ and ${ }^{15} \mathrm{~N}$ to determine dietary contribution. This method is identical to that used by Hilderbrand et al. (1996, 1999) and Jacoby et al. (1999) to distinguish between salmon, plant matter, and terrestrial meat. Estimates of dietary contribution were constrained so that no value could be $<0$ or $>100 \%$.

Scat samples from all areas were collected to determine species and relative proportions of plants and animals being ingested. While all scats encountered in the control areas were collected, only scats with $>0 \%$ non-pellet residues were collected in the treatment areas. Because stable isotopes were used to determine the relative proportion of nourishment coming from pellets, the purpose of the scat collection in the treatment area was to identify the relative consumption of other foods. Collected scats were frozen until analyzed. Frozen scats were thawed, mixed with water, and washed through 3 sieves $(4,0.7$, and $0.4 \mathrm{~mm}$, Fisher Scientific Company, Pittsburgh, Pennsylvania, USA). Scat contents were then transferred to a white enamel pan and observed under a dissecting microscope. Volume of each food item was ocularly estimated to the nearest $5 \%$, and species was determined when possible. If gross analysis could not determine species, microhistological analysis was used. Epidermal characteristics from ground scat samples were compared to index slides of plants collected from the study area or in the reference collection of the Wildlife Habitat Laboratory of Washington State University.

Foods were collected from all study areas. Digestible dry matter, digestible energy, and digestible protein content of each food were estimated from the equations and methods (total dietary fiber analyses, bomb calorimetry, and macro-Kjeldahl) of Pritchard and Robbins (1990). All samples were freeze-dried to minimize chemical changes, then ground in a Wiley mill. Berries with small seeds (e.g., huckleberry, Vaccinium parvifolium) were ground in liquid nitrogen and analyzed whole. Berries with large seeds that were usually passed intact by the bear were ground in liquid nitrogen, and the seeds and pulp separated for analysis. Sapwood was collected from trees damaged by bears during the preceding $24 \mathrm{hr}$. Bear-damaged trees were sampled to avoid differences in sapwood composition that might occur between trees being selected by bears and a random sample. However, because drying may alter sapwood composition once the bear has removed the bark, sapwood samples from damaged trees were collected by stripping bark and sapwood from healthy, nondisturbed areas immediately adjacent to the area stripped by the bear.

The nutritional value of the pelleted diet was determined in feeding trials using 3 captive black bears. The bears were held at the Bear Research, Education, and Conservation Facility at Washington State University and confined to metabolism crates for quantitative fecal collection. Dry matter and protein digestibility of the pelleted feed were calculated from 10-day total collection digestion trials as in Pritchard and Robbins (1990). Dry-matter content of the feed and all feces were determined by oven-drying at $100^{\circ} \mathrm{C}$. Protein and energy content of the feed and feces were determined by macro-Kjeldahl and bomb calorimetry. 
Use of Douglas-fir sapwood was modeled to determine the amount of sapwood and number of trees that would be necessary to meet daily maintenance requirements for bears of various size. Digestible dry-matter intake was estimated using the requirement equations of Rode and Robbins (2000). Fecal correction factors (Hewitt and Robbins 1996) were applied to the scat analysis data to calculate the average dietary content of sapwood. Average dietary protein content and dry-matter digestibility of the mixed diet were calculated using the estimated dietary content, percent crude protein, and percent dry-matter digestibility for each food item. The maximum mass of vascular tissue present in an average area of damage was calculated using a vascular tissue mass of 0.008 grams of dry matter $/ \mathrm{cm}^{2}$ (Kimball et al. 1998b) and an average area of damage of $0.4 \mathrm{~m}^{2} /$ tree (Noble and Meslow 1998).

\section{Statistical Analyses}

Mean ( \pm 1 SD) mass and body-fat changes (g/day) were calculated and compared between feeder and non-feeder bears by 2-sample $t$-tests (Zar 1984). Dietary contribution of pellets and meat were tested by analysis of variance (ANOVA; SAS Institute 1999). The slope and intercept of regressions between age and body mass were compared by analysis of covariance (ANCOVA; SAS Institute 1999, Zar 1984).

\section{RESULTS}

Fifty-three individual bears were captured 68 times in the feeder areas (Table 1). Of these, $42 \%$ were female ( 8 subadult, 14 adult) and $58 \%$ were male ( 1 cub, 16 subadult, 14 adult). Two large adult males (195 kg and $162 \mathrm{~kg}$ ) captured during the 1999 field season were not aged because they lacked premolar teeth. Twentythree bears were captured 28 times in the nonfeeder areas during the 2 field seasons. Of these, $48 \%$ were female (4 subadult, 7 adult) and $52 \%$ were male ( 4 subadult, 8 adult).

Mass gains for recaptured bears were higher in the feeder areas $(153 \pm 119 \mathrm{~g} / \mathrm{d})$ than in non-fed areas $\left(12 \pm 104 \mathrm{~g} / \mathrm{d}, t_{18}=2.36, P=0.03\right)$. Fourteen of the 15 bears recaptured in the feeder areas gained mass, whereas 4 of 5 bears recaptured in the non-feeder areas lost mass. However, there was no detectable difference in age-specific body masses between feeder and non-feeder areas for males $\left(F_{1,23}=0.08, P=0.78\right)$ or females $\left(F_{1,12}=\right.$ $1.78, P=0.21$; Fig. 1). Mass changes did not differ between males and females $(P \geq 0.3)$ in each area, so all data in each area were combined. Gains in body fat did not differ between feeder (42 \pm 50 $\mathrm{g} / \mathrm{d})$ and non-feeder areas $\left(4 \pm 59 \mathrm{~g} / \mathrm{d}, \mathrm{t}_{16}=1.75\right.$, $P=0.22)$, nor did age-class specific body-fat content $\left(\mathrm{F}_{1,43}=3.39, P=0.07\right)$. The composition of

Table 1. Body mass and fat content of black bears captured in areas with and without commercial bear pellets in western Washington.

\begin{tabular}{|c|c|c|c|c|c|c|c|c|c|c|c|c|c|}
\hline \multirow{3}{*}{ Season } & \multirow{3}{*}{ Cohort } & \multicolumn{6}{|c|}{ Areas with pellets } & \multicolumn{6}{|c|}{ Areas without pellets } \\
\hline & & \multicolumn{3}{|c|}{ Mass (kg) } & \multicolumn{3}{|c|}{ Fat $(\%)$} & \multicolumn{3}{|c|}{ Mass (kg) } & \multicolumn{3}{|c|}{ Fat (\%) } \\
\hline & & $\overline{\bar{x}}$ & SD & $\bar{n}$ & $\overline{\bar{x}}$ & SD & $n$ & $\overline{\bar{x}}$ & SD & $\bar{n}$ & $\overline{\bar{x}}$ & SD & $\bar{n}$ \\
\hline \multicolumn{14}{|c|}{$\begin{array}{l}\text { Early spring } \\
\text { (10 Apr-31 May) }\end{array}$} \\
\hline & Female & & & & & & & & & & & & \\
\hline & Subadult & 41 & 13 & 5 & 13 & 2 & 5 & 45 & & 2 & 12 & & 2 \\
\hline & Adult & 75 & 12 & 11 & 15 & 7 & 11 & 60 & 10 & 6 & 10 & 1 & 4 \\
\hline & Male & & & & & & & & & & & & \\
\hline & Subadult & 60 & 32 & 9 & 11 & 5 & 9 & 44 & 13 & 4 & 10 & & 2 \\
\hline & Adult & 145 & 35 & 11 & 19 & 5 & 10 & 120 & 35 & 8 & 12 & 6 & 8 \\
\hline \multirow{7}{*}{$\begin{array}{l}\text { Early sur } \\
\text { (1 Jun-1 }\end{array}$} & & & & & & & & & & & & & \\
\hline & Female & & & & & & & & & & & & \\
\hline & Subadult & 53 & 14 & 6 & 12 & 4 & 5 & 29 & 10 & 3 & 8 & & 2 \\
\hline & Adult & 89 & 16 & 10 & 19 & 6 & 9 & 60 & 14 & 4 & 10 & 3 & 3 \\
\hline & Male & & & & & & & & & & & & \\
\hline & Subadult & 48 & 22 & 12 & 9 & 4 & 9 & 50 & & 1 & & & \\
\hline & Adult & 90 & 15 & 4 & 12 & 4 & 4 & & & & & & \\
\hline
\end{tabular}



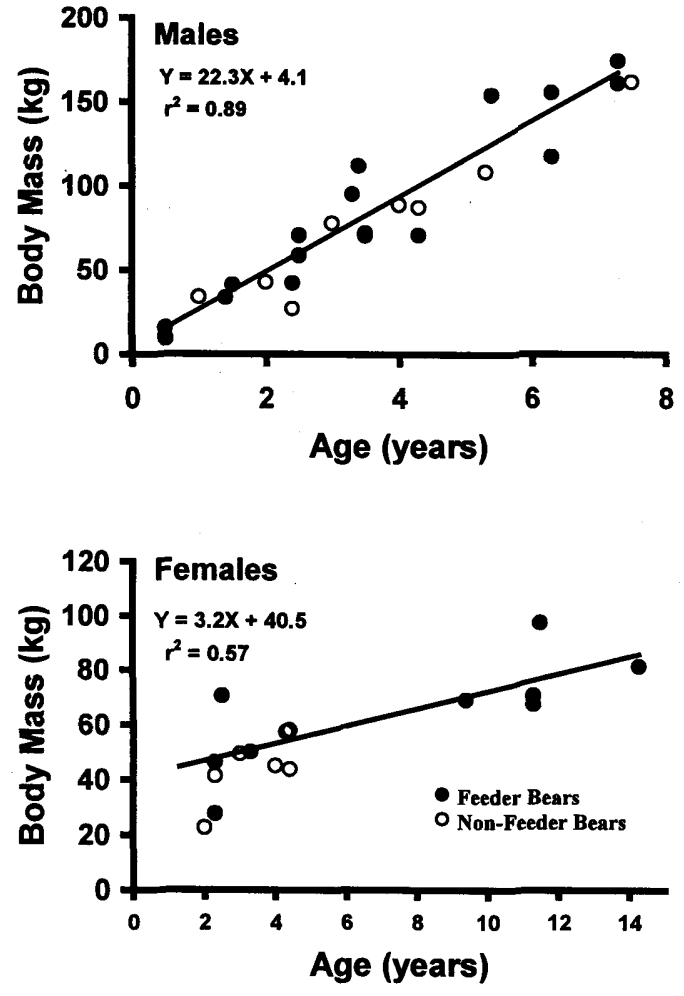

Fig. 1. Age-specific body mass of male and female black bears captured at feeder and non-feeder areas in western Washington (Poelker and Hartwell 1973, current study). Regressions are for bears in feeder areas only. Poelker and Hartwell (1973) data are age-class means for $\mathbf{3 7}$ males and 28 females.

mass changes for bears that gained mass averaged $72 \pm 13 \%$ lean body mass and $28 \pm 13 \%$ body fat. For bears that lost mass, $30 \pm 10 \%$ was lost as lean body mass and $70 \pm 10 \%$ as body fat.

Isotopic signatures of bears captured in nonfeeder areas indicated that they had no access to pellets (Fig. 2). There were no differences in dietary estimates based on plasma and red blood cells. The source of nourishment for these bears was $13 \pm 17 \%$ meat and $87 \pm 17 \%$ plant matter and did not differ by age $\left(F_{1,21}=0.12, P=0.73\right)$, sex $\left(F_{1,21}=0.64, P=0.43\right)$, or capture period $\left(F_{1,21}=\right.$ $3.25, P=0.09)$. Isotopic signatures of bears captured in feeder areas indicated diets ranging from 0 to virtually $100 \%$ pellets (Fig. 2 ). Of the 48 bears that had consumed pellets based on their isotope signature, the average diet was $55 \pm$ $22 \%$ pelleted feed, $7 \pm 7 \%$ meat, and $38 \pm 18 \%$ plant matter. The dietary content of pellets was higher for males $(61 \pm 21 \%)$ than females $(41 \pm$ $22 \%$ ) in early spring before the initial capture
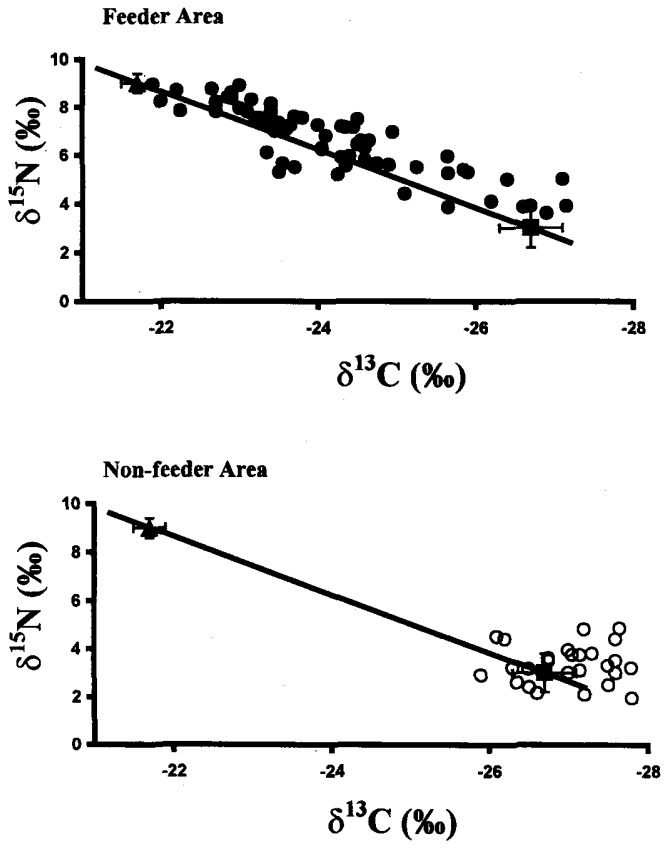

Fig. 2. Plasma isotope signatures of bears captured in feeder and non-feeder areas in spring and early summer in western Washington relative to a $100 \%$ pelleted diet $(\boldsymbol{\Delta})$ and a $100 \%$ plant diet $(\mathbf{\square}$, isotope signature of herbivorous Columbian black-tailed deer).

period $\left(F_{1,28}=8.37, P=0.02\right)$, but males $(58 \pm$ $24 \%)$ and females $(60 \pm 16 \%)$ had similar diets before the early summer recapture period $\left(F_{1,28}=\right.$ $0.01, P=0.91)$. Dietary meat content did not differ between males and females in the initial capture period $\left(F_{1,28}=0.06, P=0.80\right)$ or recapture period $\left(F_{1,28}=1.69, P=0.20\right)$. Five bears captured in April in the feeder area had not consumed pellets based on their plasma isotope signatures. When 2 of those bears were recaptured in the later capture period, they had isotope signatures characteristic of significant pellet consumption. All bears captured in the feeder areas after 30 April had consumed pellets.

The major vegetative components of the diet were grasses and sedges (Table 2). Common forbs consumed in both areas were horsetail (Equisetum arvense), cow parsnip (Heracleum lanatum), and false dandelion (Hypochaeris radicata). Forb use increased from late April to July as more plants emerged. Insects dominated the ingested animal matter, with use increasing as the season progressed.

Early-season grasses and forbs were nutritious sources of energy and protein (Table 3). 
Table 2. Percent frequency (\% of scats with item) and \% volume (sum of volumes in all scats for a specific item/total number of scats) for bear scats in feeder and non-feeder areas in western Washington.

\begin{tabular}{|c|c|c|c|c|}
\hline \multirow[b]{2}{*}{ Forage item } & \multicolumn{2}{|c|}{ Areas with pellets $(n=78)$} & \multicolumn{2}{|c|}{ Areas without pellets ( $n=46$ ) } \\
\hline & \%Frequency & $\%$ Volume & \%Frequency & \%Volume \\
\hline Graminoids & 88 & 39 & 98 & 57 \\
\hline Forbs & 65 & 19 & 87 & 32 \\
\hline Cirsium arvense & 1 & ta & 11 & 1 \\
\hline Claytonia spp. & 4 & 1 & 9 & 1 \\
\hline Equisetum arvense & 14 & 2 & 15 & 4 \\
\hline Heracleum lanatum & 15 & 2 & 7 & 1 \\
\hline Hypochaeris radicata & 14 & 3 & 22 & 3 \\
\hline Lathyrus spp. & 4 & 1 & 15 & 2 \\
\hline Lomatium spp. & 4 & $t$ & 2 & $t$ \\
\hline Lupinus spp. & 1 & $\mathrm{t}$ & & \\
\hline Lysichitum americanum & & & 9 & 2 \\
\hline Montia spp. & 1 & $\mathrm{t}$ & 9 & 1 \\
\hline Ranunculus spp. & 3 & 1 & 4 & 1 \\
\hline Rosa gymnocarpa & 8 & 1 & 5 & $\mathbf{t}$ \\
\hline Rumex spp. & 1 & $t$ & & \\
\hline Taraxacum officianale & 4 & 1 & 11 & 1 \\
\hline Trifolium repens & 10 & 1 & 11 & 1 \\
\hline Vicia spp. & 3 & 1 & 4 & 1 \\
\hline Viola glabella & 1 & 1 & 4 & 1 \\
\hline Unknown forbs & 54 & 4 & 78 & 12 \\
\hline Sapwood & 5 & 1 & 22 & 4 \\
\hline Pellets & 65 & 33 & & \\
\hline Animal matter & 36 & 6 & 35 & 4 \\
\hline Formicidae & 23 & 3 & 17 & 1 \\
\hline Hymenoptera & 4 & 1 & 7 & 1 \\
\hline Mammal & 14 & 2. & 11 & 1 \\
\hline Berry & 9 & 2 & 7 & 3 \\
\hline Mohonia nervosa & 1 & $t$ & 2 & $t$ \\
\hline Oplopanax horridum & 3 & 1 & 4 & 2 \\
\hline Rubus spectabilis & 8 & 1 & 2 & $t$ \\
\hline Rubus ursinus & 1 & $\mathrm{t}$ & & \\
\hline Vaccinium parvifolium & 1 & $t$ & 2 & $t$ \\
\hline
\end{tabular}

at-trace

Digestibility of vegetation decreased between the 2 sampling periods because of the increase in fiber content. Sapwood collected from damaged trees averaged $10 \%$ crude protein and had drymatter and energy digestibilities similar to berries.

The mass of sapwood estimated to meet the daily maintenance requirement (i.e., zero mass change) when consuming only sapwood increased from $4 \mathrm{~kg}$ fresh mass/day for a $20-\mathrm{kg}$ bear to $13-\mathrm{kg}$ fresh mass/day for a $100-\mathrm{kg}$ bear, which represents 17 trees/day and 56 trees/day, respectively (Fig. 3A). However, the estimated amount of sapwood ingested to meet maintenance requirements on the mixed diet estimated from scat analysis (sapwood $=3 \%$ of the diet) increased from $0.16 \mathrm{~kg}$ fresh mass/day for a $20-\mathrm{kg}$ bear to $0.55 \mathrm{~kg}$ fresh mass/day for a $100-\mathrm{kg}$ bear. This level of observed sapwood consumption would damage from 0.5 to 2 trees/day, respectively (Fig. 3B).

\section{DISCUSSION}

All black bears trapped in the feeder areas consumed food pellets. Although the pellets were designed to meet all nutrient requirements, bears that ate pellets continued to consume grasses, forbs, invertebrates, and other natural foods. Pellet consumption may be constrained by a desire to avoid humans or other bears. Also, adult males frequently left the feeder areas as they 
Table 3. Dry matter (DM), gross energy (GE), crude protein (CP), total dietary fiber (TDF), and apparent digestible energy (ADE) of major spring (10 Apr-31 May) and early summer (1 Jun-17 Jul) black bear foods in western Washington.

\begin{tabular}{|c|c|c|c|c|c|c|c|c|c|c|}
\hline \multirow[b]{2}{*}{ Food item } & \multirow[b]{2}{*}{ Season } & \multirow[b]{2}{*}{$\begin{array}{c}\text { Dry matter } \\
\%\end{array}$} & \multicolumn{2}{|c|}{$\begin{array}{c}\mathrm{GE} \\
(\mathrm{kcal} / \mathrm{g})\end{array}$} & \multicolumn{2}{|c|}{$\begin{array}{c}\mathrm{CP} \\
(\% \overline{\mathrm{DM}}) \\
\end{array}$} & \multicolumn{2}{|c|}{$\begin{array}{c}\text { TDF } \\
\text { (\% DM) }\end{array}$} & \multicolumn{2}{|c|}{$\begin{array}{c}\text { ADE } \\
(\% \text { DM) }\end{array}$} \\
\hline & & & $\bar{x}$ & SD & $\bar{x}$ & $\mathrm{SD}$ & $\bar{x}$ & SD & $\bar{x}$ & SD \\
\hline Clover & Spring & 14.5 & 4.4 & 0.01 & 22.6 & 2.7 & 39.6 & 4.5 & 46.4 & 5.2 \\
\hline (Trifolium repens) & Summer & 15.1 & 4.4 & 0.01 & 17.4 & 4.1 & 45.2 & 2.9 & 40.0 & 3.4 \\
\hline Cow parsnip & Spring & 17.6 & 4.3 & 0.2 & 18.7 & 2.7 & 39.4 & 2.2 & 46.7 & 2.6 \\
\hline (Heracleum lanatum) & Summer & 19.2 & 4.3 & 0.2 & 17.7 & 9.0 & 47.7 & 6.4 & 37.1 & 7.4 \\
\hline $\begin{array}{l}\text { Dandelion } \\
\text { (Taraxacum officianale) }\end{array}$ & Spring & 18.4 & 4.9 & 0.2 & 14.5 & 3.0 & 40.8 & 2.8 & 45.0 & 3.3 \\
\hline $\begin{array}{l}\text { False dandelion } \\
\text { (Hypochaeris radicata) }\end{array}$ & $\begin{array}{l}\text { Spring } \\
\text { Summer }\end{array}$ & 19.8 & 4.3 & 0.3 & 11.7 & 1.4 & 50.5 & 6.2 & 33.9 & 7.2 \\
\hline \multirow[t]{2}{*}{ Graminoids } & Spring & 23.5 & 4.5 & 0.1 & 18.4 & 2.7 & 54.8 & 1.5 & 28.9 & 1.7 \\
\hline & Summer & 26.7 & 4.5 & 0.1 & 16.8 & 2.7 & 63.9 & 4.1 & 18.4 & 5.1 \\
\hline Horsetail & Spring & 17.8 & 3.9 & 0.2 & 14.8 & 3.1 & 57.2 & 3.1 & 26.2 & 3.6 \\
\hline (Equisetum arvense) & Summer & 20.5 & 3.9 & 0.2 & 14.5 & 1.6 & 55.4 & 0.1 & 28.3 & 0.1 \\
\hline $\begin{array}{l}\text { Skunk cabbage } \\
\text { (Lysichitum americanum) }\end{array}$ & $\begin{array}{l}\text { Spring } \\
\text { Summer }\end{array}$ & 14.0 & 4.2 & 0.3 & 25.5 & 4.0 & 35.0 & 3.4 & 51.7 & 3.9 \\
\hline Douglas-fir sapwood & Spring & 10.8 & 4.7 & 0.2 & 10.5 & 0.3 & 22.0 & 2.6 & 66.8 & 3.0 \\
\hline (Pseudotsuga menziesi) & Summer & 10.8 & 4.7 & 0.2 & 11.5 & 1.5 & 22.0 & 2.9 & 66.8 & 3.4 \\
\hline Hemlock sapwood & Spring & 10.5 & 4.7 & 0.2 & 7.1 & 0.9 & 28.2 & 1.0 & 59.6 & 1.2 \\
\hline (Tsuga heterophylla) & Summer & . & & & & & & & & \\
\hline Devils-club berry & Spring & & & & & & & & & \\
\hline (Oplopanax horridum) & Summer & 24.8 & 6.1 & & 3.8 & & 25.6 & & 62.6 & \\
\hline Huckleberry & Spring & & & & & & & & & \\
\hline (Vaccinium parvifolium) & Summer & 12.3 & 4.6 & & 6.2 & & 28.4 & & 59.4 & \\
\hline Red elderberry & Spring & & & & & & & & & \\
\hline (Sambucus racemosa) & Summer & 16.5 & 5.4 & & 11.7 & & 36.6 & & 49.2 & \\
\hline Salmonberry & Spring & & & & & & & & & \\
\hline (Rubus spectabilis) & Summer & 9.9 & 4.4 & & 9.2 & & 17.3 & & 72.2 & \\
\hline Trailing blackberry & Spring & & & & & & & & & \\
\hline (Rubus ursinus) & Summer & 15.5 & 4.3 & & 5.9 & & 16.2 & & 72.5 & \\
\hline Pellets ${ }^{a}$ & & 92.4 & 4.1 & 0.1 & 22.2 & 0.6 & & & 61.2 & 1.4 \\
\hline
\end{tabular}

a Determined by captive feeding trials.

presumably searched for estrus females (S. T. Partridge, unpublished data). During these times, they would have consumed only natural foods. Thus, adult males or females did not exclude younger, subordinate bears from consuming pellets. However, if pellets were fed in restricted quantities, the feeders could become a limited, high-value, defendable resource that might lead to dominant bears excluding subordinate bears, with subsequent increased damage of surrounding trees.

Sapwood is qualitatively an excellent food resource with relatively high levels of sugar and digestible energy (Radwan 1969; Kimball et al. $1998 a$, this study). Recent studies have suggested that females and subadult males damage trees most where pellet-feeding does not occur (Collins 1999). Large males may do relatively little damage because their energy requirements are too high to efficiently exploit foods that have low ingestion rates (Welch et al. 1997, Hilderbrand et al. 1999, Rode 1999). Ingestion rates of sapwood will be limited by its relatively small mass per unit area (Kimball et al. 1998b). Although the absolute ingestion rate will be higher in larger bears with wider incisors for scraping sapwood than in smaller bears, the ingestion rate of sapwood by large bears relative to their daily energy requirements will be less than by smaller bears. For example, although energy requirements 
A.



B.

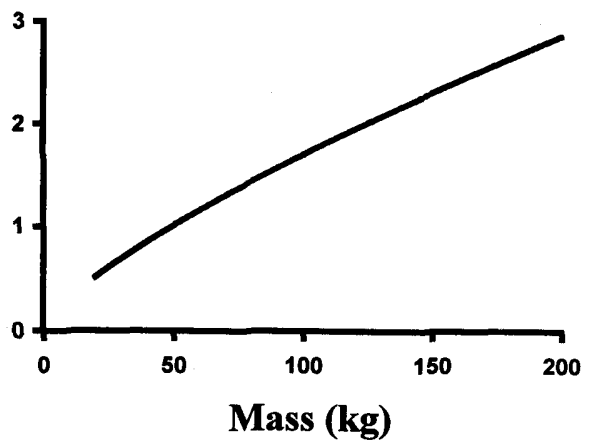

Fig. 3. Number of trees that would be damaged if a bear was meeting its maintenance requirements on a $100 \%$ sapwood diet (A) and a mixed diet containing 3\% sapwood characteristic of bears in the current study (B).

scale to body mass with an exponent of 0.75 , total incisor width of either the upper or lower jaw scales with an exponent of 0.18 (Rode 1999). Thus, an $80-\mathrm{kg}$ adult female's incisor width for scraping sapwood relative to her energy requirements is $44 \%$ greater than that of a $150-\mathrm{kg}$ male.

Bears living in feeder areas gained more mass while feeding on pellets than those living in the non-feeder area, but the lack of age-specific mass and body-fat differences suggests that non-feeder bears could compensate for short-term differences in spring mass gains with increased foraging later in the year. Bears feeding on ad libitum berries in the late summer and fall during hyperphagia can gain mass 3 to 4 times faster than growth rates observed for wild bears feeding on pellets in the spring (Welch et al. 1997). The similar composition of the spring gains in both feeder and non-feeder areas (28\% fat and $72 \%$ lean body mass) are characteristic of bears in other areas (Hilderbrand et al. 1999) and thus not influenced by pellet consumption. In summary, supplemental feeding of black bears briefly in the spring appears to be a worthwhile management option (compared to lethal alternatives) to reduce tree damage because it apparently does not produce bears that are larger or in better physiological condition than bears that are not provided supplemental feed.

\section{ACKNOWLEDGMENTS}

We are grateful to $S$. Jenkins, $K$. Rode, L. Schwartz, T. Veenendaal, J. Theade, P. Fersterer, D. Byrne, R. Flowers, M. Jones, G. Jones, M. Jacoby, G. Hilderbrand, and E. Shochat for assistance with captive and wild bear care and data collection. B. Paque, D. Hollingsworth, J. Byse, L. Hatton, G. Ruggles, G. Jones, B. Payne, M. Payne, W. Williams, and others provided expertise and dogs for bear recaptures. P. Johnson provided unlimited access to a freeze dryer to process plant samples. B. Davitt provided facilities and expertise for scat and nutritional analysis. M. Evans assisted with statistical analysis. C. Brock and the U.S. Geological Survey lab in Denver assisted with stable isotope analysis. We thank L. Shipley and R. Wielgus for comments on the manuscript. This research was supported by the Forest Resources Collaborative Research Team. This study was conducted in accordance with animal care and use guidelines and was approved by the Washington State University Institutional Animal Care and Use Committee (Protocol \# 2742).

\section{LITERATURE CITED}

Collins, G. H. 1999. Behavioral ecology of black bear damage to conifer stands. Thesis, Washington State University, Pullman, USA.

Cormie, A. B., AND H. P. SCHWARCZ. 1994. Stable isotopes of nitrogen and carbon of North American white-tailed deer and implications for paleodietary and other food web studies. Palaeogeography, Palaeoclimatology, Palaeoecology 107:227-241.

FARLEY, S. D., AND C. T. RoBbINS. 1994. Development of two methods to estimate body composition of bears. Canadian Journal of Zoology 72:220-226.

FLOWERS, R. H. 1987. Supplemental feeding of black bear in tree damaged areas of western Washington. Pages 147-148 in D. M. Baumgartner, editor. Animal damage management in Pacific Northwest forests. Cooperative Extension, Washington State University, Pullman, USA.

GLOVER, F. A. 1955. Black bear damage to redwood reproduction. Journal of Wildlife Management 19:437-443.

Hennon, P. E., E. M. Hansen, AND C. G. ShaW, III. 1990. Causes of basal scars on Chamaecyparis nootkatensis in southeast Alaska. Northwest Science 64:45-54.

HewITT, D. G., AND C. T. RoBBins. 1996. Estimating grizzly bear food habits from fecal analysis. Wildlife Society Bulletin 24:547-550. 
Hilderbrand, G. V., S. D. Farley, and C. T. Robbins. 1998. Predicting the body condition of bears via two field methods. Journal of Wildlife Management 62:406-409.

C $\longrightarrow$, T. A. Hanley, K. Titus, AND C. SERVhEen. 1996. Use of stable isotopes to determine diets of living and extinct bears. Canadian Journal of Zoology 74:2080-2088.

, S. G. Jenkins, C. C. SChwartz, T. A. HANLEY, AND C. T. RobBINS. 1999. Effect of seasonal differences in dietary meat intake on changes in body mass and composition in wild and captive brown bears. Canadian Journal of Zoology 77:1623-1630.

Hobson, K. A., AND R. G. Clark. 1992. Turnover of ${ }^{13} \mathrm{C}$ in cellular and plasma fractions of blood: implications for nondestructive sampling in avian dietary studies. Auk 110:638-641.

Jacoby, M. E., G. V. Hilderbrand, C. Servheen, C. C. Schwartz, S. M. ARThUR, T. A. Hanley, C. T. Robbins, AND R. T. MICHENER. 1999. Trophic relations of brown and black bears in several western North American ecosystems. Journal of Wildlife Management 63:921-929.

Johnson, K. G., AND M. R. Pelton. 1980. Prebaiting and snaring techniques for black bears. Wildlife Society Bulletin 8:46-54.

Kimball, B. A., D. L. Nolte, R. M. Engemann, J. J. JohnSTON, AND F. R. STERMITZ. 1998a. Chemically mediated foraging preference of black bears (Ursus americanus). Journal of Mammalogy 79:448-456.

E. C. TuRnBlom, D. L. NOlTE, D. L. GRIFFin, AND R. M. ENGEMANN. 1998 b. Effects of thinning and nitrogen fertilization on sugars and terpenes in Douglas-fir vascular tissues: implications for black bear foraging. Forest Science 44:599-603.

LuTZ, H. J. 1951. Damage to trees by black bears in Alaska. Journal of Forestry 49:522-523.

Mason, A. C., AND D. L. Adams. 1989. Black bear damage to thinned timber stands in northwest Montana. Western Journal of Applied Forestry 4:10-13.

NELSON, E. E. 1989. Black bears prefer urea-fertilized trees. Western Journal of Applied Forestry 4:13-15.
Noble, W. O., AND E. C. Meslow. 1998. Spring foraging and forest damage by black bears in the central coast ranges of Oregon. Ursus 10:293-298.

NOYCE, K. V., AND D. L. GARSHELIS. 1998. Spring weight changes in black bears in northcentral Minnesota: the negative foraging period revisited. Ursus 10:521-531.

Peterson, B. J., AND B. Fry. 1987. Stable isotopes in ecosystem studies. Annual Review of Ecology and Systematics 18:293-320.

PICKELL, B. 1997. Black bears-their café in the woods. The Springboard (November):6-8.

PoElKER, R. J., AND H. D. HARTWELl. 1973. Black bear of Washington. Washington State Game Department Biological Bulletin Number 14.

Pritchard, G. T., AND C. T. RobBIns. 1990. Digestive and metabolic efficiencies of grizzly and black bears. Canadian Journal of Zoology 68:1645-1651.

RADWAN, M. A. 1969. Chemical composition of the sapwood of four tree species in relation to feeding by the black bear. Forest Science 15:11-16.

RODE, K. D. 1999. Constraints on herbivory by grizzly bears. Thesis, Washington State University, Pullman, USA.

, AND C. T. RoBbins. 2000. Why bears consume mixed diets during fruit abundance. Canadian Journal of Zoology 78:1640-1645.

SAS INSTITUTE. 1999. SAS/STAT user's guide. Version 8 (TS MO). SAS Institute, Cary, North Carolina, USA.

WatanABE, H. 1980. Damage to conifers by the Japanese black bear. International Conference on Bear Research and Management 4:67-70.

Welch, C. A., J. KeaY, K. C. Kendall, and C. T. RobBins. 1997. Constraints on frugivory by bears. Ecology 78:1105-1119.

ZAR, J. H. 1984. Biostatistical analysis. Second edition. Prentice-Hall, Englewood Cliffs, New Jersey, USA.

Received 8 May 2000.

Accepted 24 October 2000.

Associate Editor: Hellgren. 